\title{
CHALLENGES AND PROSPECTS FOR DEVELOPMENT OF UKRAINIAN OIL AND GAS COMPLEX ENTITIES
}

\author{
Mikhail BORODIN ${ }^{1}$ \\ International University of Business and Law, Ukraine
}

\begin{abstract}
The aim of the paper is to analyze the current state of the oil and gas complex of Ukraine, upon which to identify the challenges and to justify the development prospects of the effective activities of complex entities. Comprehensive introduction of the advanced mechanisms for the development of oil and gas complex entities' development will contribute to the economic growth of other industries and the Ukrainian economy as a whole, as well as decrease in the energy dependence and security of the state interests. Methods. The following methods were used in research: systematic, economic and mathematical, balancing, judgment-based and abstract-logical. In addition, methods of statistical analysis, analytical spread sheet tabulation method, and method of scientific hypothesis modelling for studied processes. Results. The effectiveness of introduction of the proposed perspective trends of the entities of Ukrainian oil and gas complex is estimated. It is proved that their comprehensive implementation will improve the competitiveness of their operations, and energy independence of Ukraine. The necessity of introduction of the innovative technologies and new approaches to solution of the management problems at oil and gas complex entities is proved. Implementation of prospective mechanisms for the development of effective activity of oil and gas entities shall be based on economic competition between the entities with simultaneous implementation of the measures of state support for the promising modernization technologies reflecting the public interest to the energy security improvement. Practical significance. A study of the current state of oil and gas complex of Ukraine and challenges of development of the complex entities contributes to the identification of areas for balancing and substantiation of the development prospects of the oil and gas sector of economy in order to ensure its energy security, taking into account the strategic orientations of Ukrainian economy development. Implementation of the promising modernization mechanisms referred in study into practice is one of the priorities of oil and gas entities for increase in their production activities and profitability. The main sources of funds for the functioning of economic mechanisms for encouragement of the modernization programs and projects can be: funds of the state and local budgets received from the established taxes, penalties and increased payments for energy resources; own funds of the entities; credit facilities; internal and external investments. The implementation of the strategic objectives of development of oil and gas entities, introduction of large-scale measures for the development, technical upgrading and modernization of the fixed assets, as well as the consistent introduction of competitive relations on the domestic and external markets shall be fulfilled through improving the pricing and tariff policy by the introduction of the economically justified level of prices and tariffs for energy resources. Value/originality. The current state of the oil and gas complex of Ukraine is analyzed and its problems are identified, upon which its development prospects are substantiated. The main challenges inhibiting the stable development of oil and gas entities and their solutions are considered. The challenge of modernization and technical re-equipment of the oil and gas complex entities and the possibility of their organizational and economic reforming are covered.
\end{abstract}

Key words: oil and gas complex, investments, innovations, modernization, energy security.

JEL Classification: L71, E22, O31, O32, Q47

\section{Introduction}

Theme of this article is very relevant, since the production and transportation of oil and gas are the most competitive sectors of the Ukrainian economy from the standpoint of the country's integration into the system of the world economic relations.
Currently, results of oil and gas complex activities are one of the main components for the formation of the Ukrainian balance of payments, support of the national currency exchange rate, and play the pivotal role in overcoming the crisis.

The world practice has shown that in the case of implementation of major oil and gas projects, approximately

\footnotetext{
Corresponding author:

${ }^{1}$ Department of Management, International University of Business and Law.

E-mail: borodin-my@utg.ua
} 
80\% (Dunayev, Shpakov, Yepifanova, 2008) of the total volume of works falls on the share of the suppliers for the oil and gas complex: metalworking, servicing, transportation, and other companies; suppliers of equipment and metal structures, building materials, overalls, as well as research and educational institutions and many others. The "mining", "processing", "engineering" regions, power generation, construction complex of the country experience are the main effect of the oil and gas complex development. A consequential additional effect is obtained in the form of growth in the tax base, creation of new jobs, increase in the solvency of the population, etc. And we must add that in today's economy the oil and gas complex stands as an equal generator of demand for high-tech and science-intensive products.

The article is structured as follows:

- Introduction;

- Analytical section, which analyzes the current state of the oil and gas complex of Ukraine;

- Research section, which identified current challenges of development of the oil and gas complex entities;

- Recommendation section, which substantiated the possible prospects of the effective activity of oil and gas complex entities;

- Conclusion;

- Bibliography.

The aim of research is to analyze the current state of the oil and gas complex of Ukraine, to identify the challenges and to justify the prospects of development of the effective activities of the complex entities

Based on set aim, the following tasks were solved in the article:

- to characterize the current state of the oil and gas complex of Ukraine;

- to identify the relevant challenges of development of the oil and gas complex entities;

- to substantiate the prospects of effective activity of the Ukrainian oil and gas complex entities.

The following methods of research were used in the course of writing: analytical and statistical method for analysis and estimation of the current state of the Ukrainian oil and gas complex, as well for substantiation of the relevant challenges of development of the oil and gas complex entities; scientific hypothesis method in the practical recommendations regarding the prospects for the development of effective activity of the Ukrainian oil and gas complex entities.

\section{General characteristic of the oil and gas complex of Ukraine}

It is well known that the oil and gas complex is a significant sector of the Ukrainian industry. Effective functioning of its entities contributes to socio-economic development of the regions of the country, as well as other industrial branches.

Oil and gas complex is a part of the fuel and energy sector, which is seen as a complex inter-branch system of extraction and production of fuel and energy, their transportation, distribution and use.

Ukraine is one of the countries, which by using own resources meets only a little part of the demand for fuel and energy resources, which indicates the significant dependence on imported energy supplies. Thus, the consumption of gas and oil remains persistently high and satisfaction of the needs in hydrocarbons by domestic production is very low. On average, Ukraine produces about 21 billion cubic meters of gas with an annual demand of 75-80 billion cubic meters. Thus, Ukraine can independently provide itself with gas only by a quarter. A similar situation is observed in oil production. With the need for 30 million tons, Ukraine produces only 2.3 million tons, which is only $8 \%$.

Currently, there are 350 fields operating in Ukraine: oil - 78; gas - 89; gas condensate - 111; oil condensate 59; gas-oil and oil-gas - 13 (Official website of NJSC "Naftogaz of Ukraine", 2015).

In terms of the magnitude of reserves: large - 5; medium - 26; small - 319. In other words, in spite of the large number of fields, most of them are quite small and their share in the total volume of hydrocarbon production is low. The costs of construction and commissioning of small fields is not much different from the cost of commissioning of the large deposits. For this very reason, very often it is impractical from an economic point of view to explore and equip new oil or gas fields.

Most of the fields are at the final stages of development. Oil and gas industry produced $85 \%$ of proved oil reserves and $77 \%$ of natural gas reserves (Gorobets, 2011).

For instance, the two largest gas fields - Shebelinskoye and Zapadno-Krestischenskoe - are developed by $90 \%$ and $83 \%$, respectively.

Analysis of the statistical data of "Naftogaz of Ukraine" has shown that in 201519.9 billion cubic meters of gas were produced in Ukraine (in 2014 - 20.5 billion cubic meters.). The decrease in gas production was 0.6 billion cubic meters or $3 \%$ (Table 1) (Official website of NJSC "Naftogaz of Ukraine", 2015).

Table 1

Volumes of natural gas production in Ukraine in 2014-2015 (billion cubic meters)

\begin{tabular}{|l|c|c|}
\hline \multicolumn{1}{|c|}{ Oil and gas entities } & 2014 & 2015 \\
\hline Private companies & 3,3 & 3,9 \\
\hline $\begin{array}{l}\text { State Joint-Stock Company } \\
\text { "Chornomorneftegaz" }\end{array}$ & 0,3 & 0 \\
\hline PJSC "Ukrnafta” & 1,7 & 1,5 \\
\hline PJSC "Ukrgazdobycha” & 15,1 & 14,5 \\
\hline Total: & $\mathbf{2 0 , 5}$ & $\mathbf{1 9 , 9}$ \\
\hline
\end{tabular}

The volume of gas production by the state company "Ukrgazdobycha" decreased by $4 \%$ - from 15.1 to 14.5 billion cubic meters. These volumes also include production in the framework of the joint venture agreements and the produced gas is used by the company 
for its own production and processing consumption (needs).

Decrease in the volumes of gas production by "Ukrgazdobycha" enterprise occurred, in particular, over a temporary loss of control over the assets placed in the area of the ATO (Anti-Terrorist Operation) (185 million cubic meters), and also over a significant shortfall in the exploration of new areas and development of fields within several consecutive years.

The resource base of the company was exhausted: during eight years, from 2007 to 2014 , only 4 special permits for the exploration of new areas had been received, instead of the 100 required permits. At the same time, in the previous three years the entity produced about 45 billion cubic meters of gas, and the increment in reserves only by 29 billion cubic meters as compared to the required level of 150 billion cubic meters.

In 2015, "Ukrgazdobycha" company received 20 special permits and reached fivefold increase in the volumes of seismic works. Due to increase in the revenues and measures to improve the financial performance, the company has managed to intensify the development and exploratory drilling works, as well as to put into operation three booster compressor stations. The implementation of this program of actions enabled to avoid a large reduction in production capacity in 2015. "Ukrgasdobycha" company has announced about its plans to increase gas production to 20 billion cubic meters per year by 2020 under the program "Strategy20/20" (Burlaka, 2012).

In 2015 PJSC "Ukrnafta” has reduced the volume of gas production by $13 \%$ - from 1.7 to 1.5 billion cubic meters.

At the same time, the private producers have increased production by $17 \%$ - from 3.3 to 3.9 billion cubic meters.

Because of the loss of AR of Crimea, last year Ukraine did not receive gas from the State Joint-Stock Company "Chornomorneftegaz". During the first two months of 2014, 0.3 billion cubic meters of gas were produced (in 2013 - 1.7 billion cubic meters).

All marketable gas produced by oil and gas entities is purchased by NJSC "Naftogaz of Ukraine" and supplied for the needs of Ukrainian consumers at a price set by the state.

A significant reduction in the volume of oil and gas production in Ukraine for the analyzed period could affect the energy security of Ukraine's regions. In this connection there is need for an integrated research of the oil and gas complex and development of promising areas of its development as a strategic sector that provides economic and energy security of each state.

Energy transit potential of Ukraine is represented by the oil transportation and gas transportation systems, which is a strategic vector of development both of fuel and energy complex and the economy as a whole.

Ukrainian gas transportation system is the second-largest system in Europe in terms of production capacity, next to Russian system, consisting of the main gas pipelines with a total length of 39.8 thousand $\mathrm{km}$; about 50-60 billion cubic meters of gas are annually transported to Ukrainian consumers and to the countries of Western and Central Europe - 110-120 billion cubic meters of natural gas. Currently, it is technically possible to increase the gas transit to the countries of Central and Western Europe to 142 billion cubic meters per year without the expansion of the gas transportation system (Official website of NJSC “Naftogaz of Ukraine”, 2015).

It has been established that Ukraine has a powerful energy transit potential, which should become a strategic goal of oil and gas industry development in order to reduce energy dependence and promote the national interests.

\section{Challenges of development of Ukrainian oil and gas complex entities}

A typical feature of the Ukrainian oil and gas complex is the lack of competition among enterprises of this industry. Virtually all oil and gas production is controlled directly by the state in the person of NJSC "Naftogaz of Ukraine" and it is sells petroleum products to the consumers. NJSC "Naftogaz of Ukraine" is a vertically integrated oil and gas company engaged in full cycle of operations in exploration and development of the deposits, exploitation and exploratory drilling, transportation and storage of gas, supply of natural and liquefied gas to consumers. On the one hand, it is a positive point, since the state holds the strategic sector of the economy, enabling it to control and regulate all relations in this field fully, ranging from the development of individual projects of new deposits and preservation of the old fields to the sale of products to the population. However, on the other hand, such control is not always conducive to the development of these entities, since they are restricted in decision-making, in particular concerning the modernization, investments and so on.

Thus, it is possible to group the challenges of oil and gas entities to be addressed for improvement of the operation of the entire oil and gas industry.

Firstly, Ukraine takes one of the last places in the world in terms of oil refining. The plants require major reconstruction, degree of depreciation of the fixed assets exceeds $80 \%$, some of them were built in the early 1940 s, the other ones - after the war. The plants have few secondary processes deepening oil refining, which occupy $10 \%$ with respect to the primary processes, and hence there are more wastes and low yield of light products (Burlaka, 2012).

Secondly, the period of technical and technological potential of the oil and gas industry is nearly over, there is a mass decommissioning of the facilities. The average depreciation of the fixed assets in the oil industry is $60 \%$, in the gas industry - more than $57 \%$. The most significant technological problems include a high degree of deterioration of the oil and gas pumping equipment and backward production technologies, which often leads to breakages of the equipment. Some producing wells are operated at an accelerated rate, with gross violations. Disadvantages of the technological nature concern not only the production of hydrocarbons, but also exploration 
works. And here the difficulty lies in the backwardness of domestic technologies and technical capability.

Thirdly, the exploration works are chronically underfunded, so the ratio of stocks growth and production is $60 \%$. Among the geological problems of the oil and gas complex at the stage of hydrocarbons production, the most important are natural depletion of mineral resources and easily accessible reserves, as well as the emergence of a significant number of hardly accessible deposits.

Fourthly, the economic problems that directly affect the efficiency of economic activities. One of the most significant economic challenges is the outflow of foreign investments and the "escape" of domestic capital abroad. Ukrainian oil and gas complex is becoming less attractive for the investors due to the tightening of state control, introduction of restrictions for foreign businesses in the sector and sanctions from some government agencies. The outflow of Ukrainian capital is associated with the economic and political crisis, globalization of economic processes, corruption and bureaucracy in the country (Sherstuk, 2006).

A number of economic challenges in the oil and gas complex entities are also stipulated by existing tax system, frequent changes in the tax legislation.

Fifthly, the lag of our country from countries with welldeveloped oil and gas complex by all major indicators of innovation activities.

The innovation challenges, in turn, are associated with the lack of funding of the research and development centers and laboratories, as well as research and development works. In Ukraine, there are few centers that would be actively engaged in development in the oil and gas complex, therefore there is a reduction in the quality of exploration and production of fields, insufficient attention is paid to the improvement of drilling technologies. The consequence is an increase in costs for the construction of wells and net cost of the produced hydrocarbons.

From all has been said it follows that the current state of the oil and gas industry of Ukraine needs a major modernization: it is necessary to introduce innovative technologies, new approaches to the solution of urgent problems, but without science - fundamental, industry, university, adjacent - it's pointless to start (Evpanov, 2011).

Leading areas of these problems' solutions include: an increase in exploration works on the natural gas and oil fields, modernization and technical re-equipment of oil and gas refineries, increased capital investments (Figure 1).

\section{Prospects of development of the Ukrainian oil and gas complex entities}

In order to solve the above described challenges, the following main practical recommendations can be distinguished for prospective development of oil and gas complex entities, which should provide the economic stability and energy security of the country:

- expansion of exploration works, discovery of new deposits, creation of reserves and the development of mineral resources in the areas of hydrocarbon production; - application of new efficient technologies for the extraction of oil and gas, development of new methods of enhanced oil recovery, intensification of the development of deposits;

- introduction of a flexible taxation system, differentiated tax depending on the profitability of the company or differentiated rates of mineral extraction tax on certain criteria;

- development of deposits of international importance, search for partners, foreign companies with advanced technologies of exploration and production of oil and gas, etc.

Currently, the oil and gas entities operate with underload, and some are idle. Therefore, the issues related to the construction of an integrated system of innovative development of the Ukrainian oil and gas complex are of key importance. It is necessary to develop an effective organizational and economic mechanism that would facilitate the introduction of innovative technologies, possibly resulting in increase in the volumes of processing

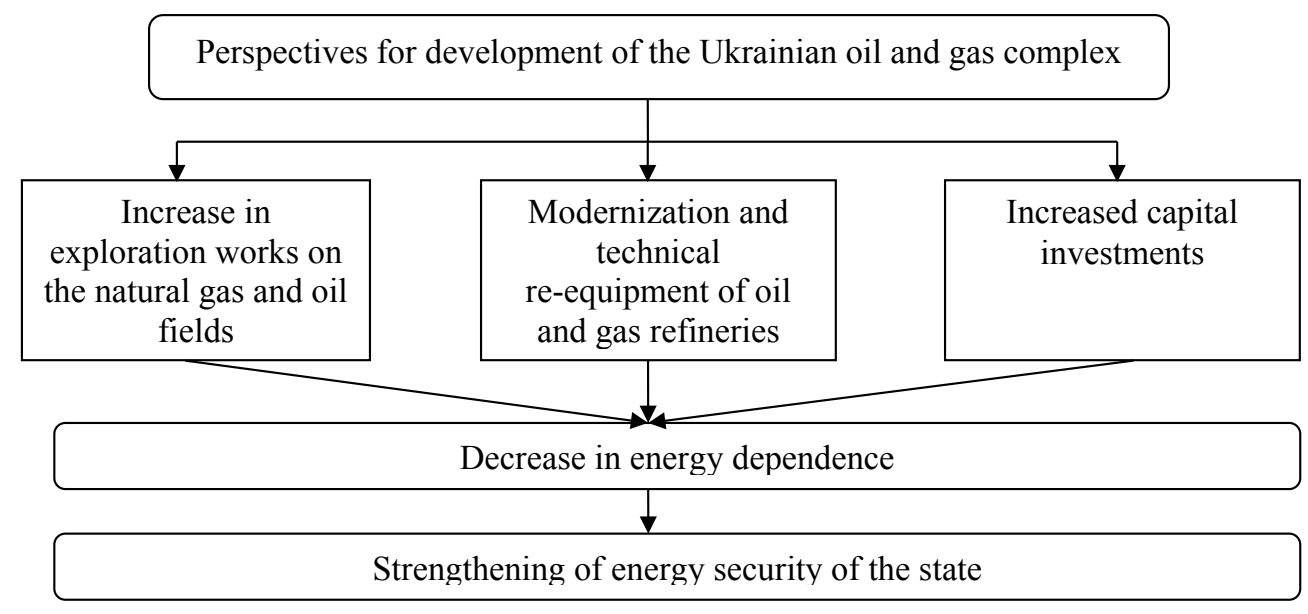

Fig. 1. Long-term model of development of oil and gas complex of Ukraine 
and transportation of oil and gas products by the Ukrainian oil and gas complex entities. And the results of their operation will be of higher quality and more economical, that will make them competitive in the domestic and foreign markets.

Most scientists believe that the increase in oil and gas production on existing fields through the introduction of new technologies and innovations is more effective trend of oil and gas complex development. The introduction of new technologies should provide a multiple increase in hydrocarbon production efficiency, as opposed to $10-15 \%$. The main directions of innovative development of oil and gas complex should be the use of modern technology and information, science-driven and energy-saving technologies. All this shall primarily reduce the cost of oil and gas production by at least $20-30 \%$.

Currently, the oil recovery rate in average in Ukraine is only 0.224 , while in the Western region -0.164 . Therefore, the more promising trend of development of the Ukrainian oil enterprises is an introduction of the innovations that will improve the hydrocarbon recovery factor from existing sources.

This can be achieved through enhanced oil recovery, which will provide an increase in the resource base and growth in oil and gas production.

Increase in the gas extraction rate in old fields can be achieved by geological and engineering tools such as hydraulic fracturing, infill drilling, increase in the development of objects, reduction of the operating pressure in gas-industrial systems, intensification of the gas flow to the foreheads of operated wells, removal of fluid from the well bottom, selection of the produced water, which entered the deposit (Burlaka, 2012).

In carrying out these activities, the oil and gas entities are faced with the problem of search for financial resources for the innovations introduction. The possible sources of investment in the development of oil and gas entities are: foreign investments, joint ventures, own funds of entities, credit and budget resources. The main source of funding for innovation should be own funds of the entities. This practice exists in many foreign companies. In such a way, the experience of the world's mining companies Shell, British Petroleum can be cited as an example. They annually spend from 3\% to 5\% of their pre-tax profit for Research and Advanced Development. Practice has proved that each extra hryvnia invested in the oil and gas complex provides a further 1.5-1.6 hryvnias.

Thus, it is necessary to reconsider the organizational and economic mechanism of business process management in the oil and gas industry entities, which will enable complete realization of the benefits of new technologies and human resources. First of all, it concerns the search for ways to improve the operating effectiveness of the oil and gas industry entities at the expense of internal reserves. This is the lever, by which industry entities have the opportunity to influence on their own production performance in any of the circumstances of economic development of Ukraine.

Solution of the challenges of oil and gas complex entities, improvement of their operation efficiency will contribute to the economic growth of other industries and the Ukrainian economy as a whole.

\section{Conclusion}

Currently, the oil and gas industry of Ukraine definitely plays a key role not only in the structure of fuel and energy complex, but in the economy as a whole. Ensuring a sufficient level of development of the oil and gas complex entities is a necessary condition for sustainable development of any country, since apart from purely commercial activities, the entities of this complex play an important social role, providing the population, institutions and municipal consumers with the natural gas.

Among others, the main problems of development of the Ukrainian oil and gas complex entities are: depletion of oil and gas fields, obsolescence of material and technical base of the oil and gas production, high net cost of oil and gas production, low level of innovation and investment activities, and so on.

Analysis of the main directions, mentioned strategic objectives will enable to develop ways to improve the economic development of the Ukrainian oil and gas complex entities. Given the strategic importance of oil and gas industry for the economy of the state, the problems of Ukraine's resource-dependence, solving of these problems is urgent. In order to achieve positive results in this area it is required to solve important tasks. They include stimulating the innovation processes and the search for sources of their funding. In the future, the oil and gas industry shall become one of the industries with an extremely high degree of capital and production concentration. A necessary condition for strategic innovative breakthrough in Ukrainian oil and gas complex is building of the appropriate mechanism for its implementation, which is formed on the long-term forecasts of socio-economic, and innovation and technological development, long-term innovation policy and energy strategy. In the case of the creation of a favourable investment climate in the country, by 2030 Ukraine will be able to reach the level of complete selfproduction of own gas by energy efficiency and increase in the production of conventional and unconventional resources.

\section{References}

Evpanov, E. (2011). Modernization of the economy should be started with the oil and gas complex - Moscow, Russian Business Newspaper. - No. 783/1 dated 11.01.2011.

Dunayev, V.F., Shpakov, V.A., Yepifanova, N.P. et al. (2008). The economy of oil and gas industry entities. 3rd edition, revised. - Moscow, TsentrLitNefteGaz, 305 p. 
Gorobets, V. (2011). Estimation of the development trends of oil and gas complex in Ukrainian regions. Retrieved from: http://nbuv.gov.ua

Burlaka, V.G. (2012). Ukrainian oil sector development strategy - Kiev, NAU, 356 p.

Sherstuk, R.V. (2006). Ways for modernization of the Oil Refinery of Ukraine - Kiev, Oil refining and Petroleum Chemistry, No. 11, p. 5-10.

Official website of NJSC "Naftogaz of Ukraine". (2015). Retrieved from: http://www.naftogaz.com

\section{Михаил БОРОДИН}

ПРОБЛЕМЫ И ПЕРСПЕКТИВЫ РАЗВИТИЯ ПРЕДПРИЯТИЙ НЕФТЕГАЗОВОГО КОМПЛЕКСА УКРАИНЫ

Аннотация. Целью работы является анализ современного состояния нефтегазового комплекса Украины, на основе которого выявить проблемы и обосновать перспективы развития эффективной деятельности предприятий отрасли. Комплексное внедрение перспективных механизмов развития деятельности предприятий нефтегазового комплекса будет способствовать экономическому росту других отраслей и украинской экономике в целом, а так же уменьшению энергетической зависимости и обеспечению государственных интересов. Методика. В исследовании использовались методы: системный, экономикоматематический, балансовый, экспертный, абстрактно-логический. Также использовались методы статистического анализа, методы построения аналитических таблиц, моделирования научной гипотезы изучаемых процессов. Результаты. Осуществлена оценка эффективности реализации предложенных перспективных направлений развития предприятий нефтегазового комплекса Украины. Доказано, что их комплексная реализация позволит улучшить уровень конкурентоспособности их деятельности и энергетической независимости Украины. Доказана необходимость внедрения инновационных технологий и новых подходов к решению управленческих задач на предприятиях нефтегазового комплекса. Реализация перспективных механизмов развития эффективной деятельности предприятий нефтегазового комплекса должна происходить на основе экономической конкуренции между предприятиями с одновременным внедрением мер государственной поддержки перспективных технологий модернизации, отражающие общественный интерес по повышению уровня энергетической безопасности. Практическое значение. Исследование современного состояния нефтегазового комплекса Украины и проблем развития предприятий отрасли способствуют выявлению направлений сбалансирования и обоснования перспектив развития нефтегазового сектора экономики с целью обеспечения ее энергетической безопасности с учетом стратегических ориентиров развития украинской экономики. Внедрение указанных в исследовании перспективных механизмов модернизации в практику является одним из приоритетных направлений работы нефтегазовых предприятий по увеличению их производственной деятельности и обеспечению прибыльности. Основными источниками поступления средств для функционирования экономических механизмов стимулирования программ и проектов модернизации могут быть использованы: средства государственного и местных бюджетов полученные от установленных налогов, штрафов и повышенной платы за энергоресурсы; собственные средства предприятий; кредитные ресурсы; внутренние и внешние инвестиции. Реализация стратегических задач развития предприятий нефтегазового комплекса, внедрения масштабных мероприятий по развитию, технического обновления и модернизации основных фондов, а также последовательное внедрение конкурентных отношений на внутреннем и внешних рынках должно осуществляться путем совершенствования ценовой и тарифной политики путем внедрения экономически обоснованного уровня цен и тарифов на энергоносители. Значение/оригинальность. Проведен анализ современного состояния нефтегазового комплекса Украины и определены его проблемы, исходя из которых, обоснованы перспективы его развития. Рассмотрены основные проблемы, препятствующие стабильному развитию предприятий нефтегазовой отрасли и пути их решения. Затронута проблема модернизации и технического переоснащения оборудования предприятий нефтегазовой отрасли и возможности их организационно-экономического реформирования. 